\title{
0 uso dos extratos vegetais da Caatinga e da Amazônia para produção de fitocosméticos
}

\section{Paula Cristina Barros Paiva e Reinaldo Farias Paiva de Lucena $^{2}$}

${ }^{1}$ Universidade Federal da Paraíba. Centro de Ciências Exatas e da Natureza. Programa de Pós-Graduação em Desenvolvimento e Meio Ambiente. Campus I. João Pessoa-PB, Brasil (CEP 58051-900).*E-mail: paulacrisfisio@hotmail.com.

${ }^{2}$ Universidade Federal da Paraíba. Centro de Ciências Exatas e da Natureza. Departamento de Sistemática e Ecologia. Programa de Pós-Graduação em Desenvolvimento e Meio Ambiente. Campus I. João Pessoa-PB, Brasil (CEP 58051-900).

Resumo. 0 aumento da consciência da população sobre a questão da sustentabilidade trouxe uma visão sobre a preocupação ambiental e com isso alguns consumidores passaram a utilizar produtos cosméticos naturais, de forma que o extrativismo da matéria prima provoque mínimo ou nenhum impacto, por se tratar de fonte renovável, partindo disto as empresa priorizam como mão de obra a comunidade local, pelo fato de ter o conhecimento da região e o interesse em manter a floresta apta à produção, gerando um mercado econômico para estes produtos. A Amazônia é a maior produtora de matérias primas para este ramo, porém a região da Caatinga também possui potencial para os fitocosméticos, o que falta é um olhar empresarial e de pesquisa, para explorar a região e com isso contribuir para o alavanque econômico do bioma. Partindo deste cenário, o objetivo desta pesquisa foi de traçar um perfil do consumidor de fitocosméticos acerca do conhecimento das matérias primas utilizadas nos produtos. É constatado que a transmissão de conhecimento acontece através das gerações e que a Aloe vera foi a planta mais citada com os seus benefícios propagados. Foi comprovado através das respostas do questionário a afirmação de que esses consumidores possuem preocupação com o meio ambiente, com a saúde da pele, no uso do que é natural evitando reações tóxicas.

Palavras-chave: Fitocosméticos; Consumidores; Bioma amazônico; Bioma da caatinga.

Abstract. The use of Caatinga and Amazon plant extracts for the production of phytocosmetics. The increasing population awareness of sustainability issues has brought insights into environmental concerns and, as a result, some consumers have started to use natural cosmetic products, so that the extraction of raw materials causes minimal or no impact, as it is a renewable
Recebido

21/01/2020

Aceito

22/04/2020

Disponível on line

23/04/2020

Publicado

$30 / 04 / 2020$

Acesso aberto

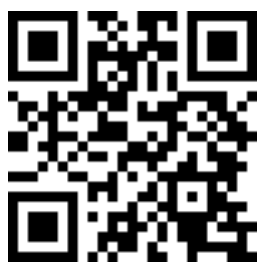

ORCID

(D) 0000-0001-9408-9250

Paula Cristina Barros

Paiva

(D) $0000-0003-4775-7775$

Reinaldo Farias Paiva

de Lucena

ISSN 2359-1412/RBGAS-2020-0011/2020/7/15/13/171

Rev. Bras. Gest. Amb. Sustent.

http://revista.ecogestaobrasil.net 
source. Based on this, the companies prioritize the local community as labor force, because they have knowledge of the region and an interest in keeping the forest able for production, generating an economic market for these products. The Amazon is the largest producer of raw materials for this branch, but the Caatinga region also has potential for phytocosmetics, even though it lacks a business and research look, to explore the region and thereby contribute to the economic leverage of the biome. From this scenario, the objective of this research was to draw a profile of the phytocosmetics consumer about the knowledge of the raw materials used in the products. It is found that the transmission of knowledge happens through the generations and that Aloe vera was the most cited plant with its propagated benefits. It was proved through the answers of the questionnaire, the statement that these consumers have concern with the environment, with the health of the skin, in the use of what is natural, avoiding toxic reactions.

Keywords: Phytocosmetics; Consumers; Amazonian biome; Caatinga biome.

\section{Introdução}

Conforme a Resolução ANVISA RDC no 7/2015, "cosméticos são preparações constituídas por substâncias naturais ou sintéticas, e suas misturas, para uso externo em diversas partes exteriores do corpo humano, pele, sistema capilar, unhas, lábios e órgãos genitais externos, dentes e as membranas mucosas da cavidade bucal, com o exclusivo ou principal objetivo de limpar, perfumar, alterar a aparência, corrigir odores corporais, protegê-los e manter em bom estado" (Brasil, 2015).

No entanto, o termo fitocosméticos são os cosméticos que possui em sua base produtos vegetais. Este componente da ciência dermocosmética é voltado a pesquisa e ao emprego da eficácia das substâncias extraídas de gêneros vegetais, tendo como grande aliada a biodiversidade brasileira, com aplicabilidade nas mais diferentes áreas, no que se refere a higiene pessoal, a produtos específicos para a estética, bem como aqueles utilizados para regeneração e os que mantém cabelo e pele sadios. Este segmento apresenta o uso dos extratos vegetais como substituto dos derivados minerais e animais, que de acordo com os estudos mais atuais, já não são mais indicados como substância cosmética (Araújo et al., 2010). 0 fitocosmético é conceituado como um produto que tem em sua base substancias de origem natural e vegetal, podendo ser um óleo, extrato ou óleo essencial, porém o efeito biológico determina a ação do produto (Figueiredo, 2014). A utilização de plantas medicinais na promoção da saúde é uma prática antiga realizada na atualidade por diversas comunidades (Santos et al., 2016).

O uso dos cosméticos vem desde os tempos pré-históricos, porém a finalidade era bem diferente comparado aos dias atuais, onde o propósito era adornar e camuflar. As matérias primas eram corantes de origem vegetal e mineral, usado como uma necessidade para se defender, porém essas bases extraídas tinham natureza tóxica e irritante a pele, com componentes prejudiciais à saúde, como o sulfeto e o carbonato de chumbo (Lyrio, 2011).

Ainda na antiguidade, a figura de Cleópatra, conhecida como a rainha do Egito, considerada um dos marcos da beleza e vaidade, os seus hábitos estimularam a pesquisa cosmética. Um primeiro formulário chamado Cleopatre Gynoecirium Libri, editado durante 
o seu reinado, onde descreve os cuidados higiênicos e tratamentos de diversas afecções cutâneas, bem como fórmulas farmacêuticas à base de plantas e óleos vegetais com finalidade terapêutica e cosmética (Teske e Trentini, 2001). Existem registros históricos, que apontam que ela se banhava com leite de cabras para manter o cabelo e pele hidratados (Galembeck e Csordas, 2009).

Partindo para o Oriente, o uso dos produtos naturais propagandeou para o mundo grego, tendo surgido no ano IV o formulário de Ovídio chamado "Os Remédios Para o Rosto Feminino", material escrito aplicado a área da cosmética, e no qual são descritas receitas e pomadas da época à base de vegetais (Camargos et al., 2009). Desde esta época, o estudo dos vegetais e o uso dos seus constituintes, seja na forma de extratos ou substâncias ativas isoladas, tem conquistado cada vez mais espaço na indústria cosmética moderna e atual.

0 mercado atual encontra-se em constante evolução, a indústria cosmética aposta nos fitocosméticos, ramo já conhecido pela indústria brasileira, porém vem se tornando uma tendência mundial e nacional. Conforme os informes da Associação Brasileira da Indústria de Higiene Pessoal, Perfumaria e Cosméticos (ABIPHEC), este novo segmento tem como foco principal o conhecimento das plantas, para então constatar seu efeito benéfico, para isso é necessário investir em pesquisas, tomando como ponto de partida o conhecimento de culturas regionais e tradicionais, fazer um diagnóstico das espécies etnobotânicas da região, para poder planejar um estudo cientifico e assim converter os resultados em tecnologia e produtos (ABIPHEC, 2019).

Os benefícios da utilização dos extratos vegetais como componente cosmético reporta à biodiversidade brasileira, pois é indubitável a vasta riqueza vegetal da Floresta Amazônica, a categoria torna-se valorizada e favorecida pela associação que faz a postura "politicamente correta", tendo como vantagem se tratar de fontes renováveis. Além da Amazônia, o Brasil oferece outras regiões como a "Caatinga, Pantanal e Pampa que totalizam 10 regiões fitoecológicas e 31 formações vegetais, entre florestas e savanas". Estão incluídas algumas miniformações geográficas regionalizadas, como sertão, brejo, agreste, cariri e curimataú no nordeste brasileiro (Forzza et al., 2010).

É interessante contextualizar que a Amazônia se destacou no Brasil e no mundo, no ramo dos fitocosméticos, devido a uma grande empresa da área que apresentou uma variada linha de cosméticos, onde foi utilizado matéria prima da biodiversidade brasileira. O manejo sustentável é uma preocupação das empresas fornecedoras de matérias-primas, evidenciando a importância do caboclo como parte indispensável nesse processo, pois devido ao seu conhecimento, o mesmo vai priorizar o seu ganho com a extração e ainda manter a floresta produtiva, pois caso contrário não terá a matéria prima desejada pelos compradores e com isso pode vim a prejudicar o seu ciclo econômico (Isaac et al., 2008).

A hipótese do presente estudo condiz que o conhecimento dos consumidores, são restritos diante das inovações do mercado do ramo, que ainda necessita de uma ampla divulgação das empresas com destaque para os extratos vegetais em uso e os seus benefícios.

Dentro desta perspectiva, em termos de pressupostos teórico-prático o estudo objetiva estabelecer o perfil dos consumidores de produtos fitocosméticos de várias regiões do Brasil. Como objetivos específicos temos: a) Levantar as propriedades das matérias-primas que são utilizadas na fabricação de fitocosméticos derivados de plantas da região amazônica e caatinga; b) Analisar o nível de conhecimento dos consumidores acerca das matérias primas usadas nos fitocosméticos; c) Entender o impacto econômico causado pelas empresas de cosméticos nas regiões de coleta e se há benefícios para as populações tradicionais.

Diante da coleta dos dados a seguinte pergunta foi respondida: qual o nível de conhecimento dos consumidores acerca do uso das matérias primas para a produção dos fitocosméticos? 
A pesquisa justifica-se pelo interesse em estudar o perfil dos consumidores de fitocosméticos sob a ótica do potencial de matéria prima das regiões da Caatinga e Amazônia, as duas caracterizam-se por serem economicamente opostas e com riquezas particulares, se assemelham pela falta de maior exploração da sua capacidade etnobotânica para tal finalidade.

A região da Caatinga é destaque na pesquisa, devido ao fato de ser uma área que se projeta no nordeste Brasileiro, e sua riqueza peculiar vem atraindo as indústrias cosméticas, devido à pouca exploração das suas maiores potencialidades. Enquanto que a região da Amazônia, já é consagrada quanto a sua riqueza de matérias primas para este ramo, mas ainda há uma grande fatia de espécies a serem estudadas e utilizadas na cosmética. Alguns estudos confirmam essa teoria, como Maia et al. (2017), que mecionam a grandiosa biodiversidade vegetal da Caatinga e sua riqueza ainda não conhecida de gêneros com finalidade cosmética, principalmente para produção de óleos essenciais, e Sousa et al. (2016), que afirma que na Região Amazônica a sua imensa biodiversidade simboliza a suprema potência do Brasil na atualidade no ramo.

\section{Material e métodos}

\section{Coleta de dados}

As informações foram obtidas através de um questionário virtual estruturado contendo quatro blocos totalizando 27 questões, sendo a maioria de múltipla escolha, os quais foram nomeados da seguinte forma: o primeiro foi a coleta dos dados pessoais, seguido pelos fitocosméticos, onde foi explorado de forma objetiva o conhecimento dos entrevistados, o terceiro bloco abrange as preocupações ambientais, onde aborda de modo especifico a relação das empresas e a consciência ecológica das mesmas e por fim o consumo de produtos naturais, onde destaca os cosméticos naturais e as razões da escolha pelos produtos .Os atributos para a escolha dos blocos citados, foi de analisar o perfil dos consumidores acerca do nível sócio econômico, correlacionando com o uso e nível de conhecimento acerca da matéria prima dos fitocosméticos, convergindo para a questão ambiental, destacando a questão dos benefícios para a classe extrativista e por fim a questão da preferência pelo consumo de cosméticos naturais ao invés dos industrializados sinteticamente.

O questionário é tido como um meio para coleta de dados formado por uma sequência de questões, que são respondidas, neste caso sem a presença do entrevistador (Marconi e Lakatos, 2002).

É observado atualmente a importância das relações virtuais no dia a dia dos indivíduos, desta forma a Internet é uma ferramenta de oportunidades para o levantamento não aleatório de dados e de modo específico para pesquisas científicas, que não procura algo geral, e sim especifico. Nesta pesquisa, os consumidores foram identificados através de conhecimento prévio da pesquisadora e assim contactados via online (Baltar e Brunet, 2012).

A divulgação do questionário foi feita preferencialmente nas redes sociais da pesquisadora e do orientador. A coleta de respostas foi limitada pelo número de questionários, quantidade suficiente para que houvesse informações para o desenvolvimento da pesquisa. No período da coleta o questionário permaneceu online e repetidamente divulgado, onde foram coletados um total de 123 instrumentos.

O questionário foi transportado para uma plataforma online (Google Forms) visando facilitar o acesso e participação de indivíduos adultos das diferentes regiões do Brasil. 0 período de coleta foi de abril a junho de 2019 para que fosse alcançado o maior número de questionários completamente preenchidos. Para uma ampla divulgação do instrumento, foi postado o link do questionário em diversos ambientes virtuais como redes sociais e e-mails. 
A tendência do perfil do usuário de extratos vegetais foi identificada a partir do uso estatístico da MODA, mediante a avaliação dos atributos verificados pelas respostas de todos os questionários respondidos. Onde a MODA é dado mais frequente de um conjunto no rol de dados.

A plataforma utilizada para hospedar o questionário foi a do site formulários Google no site www.google.com/intl/pt-BR/forms/about/ e o link https://docs.google.com/spreadsheets/d/14UTmu40heEQuY8XNslwzQPzmyVKTruxWO3 aEI0-zOcY/edit?ts=5cbdbf0f\#gid=582150943.

Na percepção da pesquisadora, as vantagens da pesquisa utilizando o questionário online, foi a oportunidade de incluir vários tipos de perguntas; custos reduzidos; o alcance de populações de difícil acesso. Enquanto que as desvantagens, advém do viés amostral, o que se traduz pela acessibilidade da população à Internet, o que se constitui como uma parte amostra da população total; a dificuldade em manuseio com o instrumento pela falta de experiência online dos respondentes; a chance de falta entendimento com as instruções de questionários auto aplicados; o não interesse em contribuir, pela falta de tempo ou de uma pessoa presente que incentive a responder e falar sobre a importância do referente estudo, a possibilidade de obter baixas taxas de resposta em alguns casos, o que dependerá do uso de formas de contato personalizadas (Baltar e Brunet, 2012).

\section{Resultados e discussão}

Atualmente, é observado o aumento do interesse dos consumidores por cosméticos chamados naturais, devido à preocupação com a pegada da sustentabilidade e por ser menos agressivo ao meio ambiente (Fonseca-Santos et al., 2015).

\section{Dados pessoais}

A maioria dos respondentes tem idade entre 30 e 34 anos (60\%). 0 alcance maior a este público se deve ao fato da forma como a divulgação do instrumento foi conduzida e direcionada de modo especifico aos estudantes e profissionais da área (Figura 1).

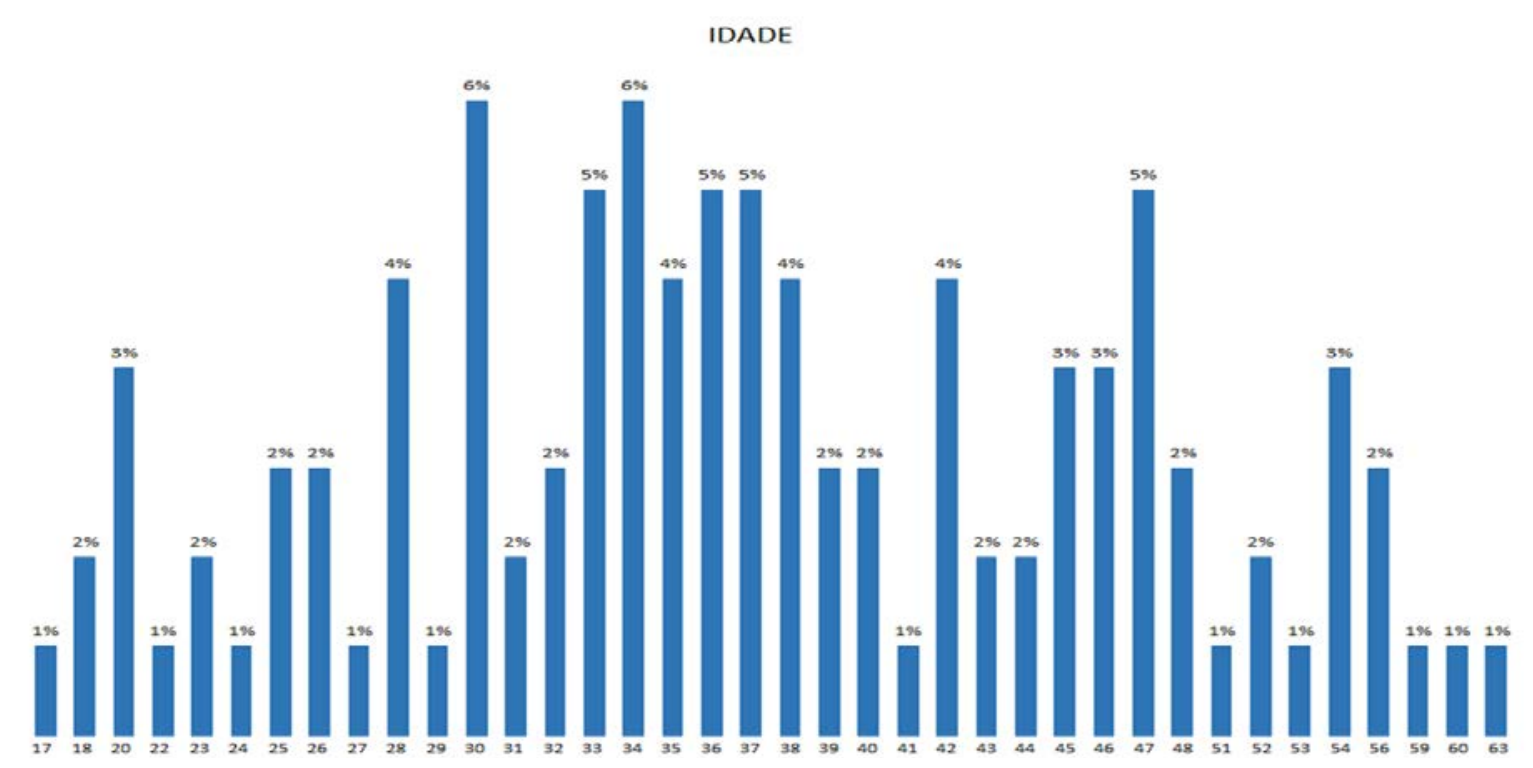

Figura 1. Idades declaradas pelos participantes da pesquisa. 
Durante o período em que ficou disponível e foi divulgado o questionário aos especialistas os respondentes, foram majoritariamente mulheres $(75,5 \%)$, esse alto índice de público, deve-se a quantidade de profissionais na área serem do sexo feminino (Figura 2).

\section{Sexo}

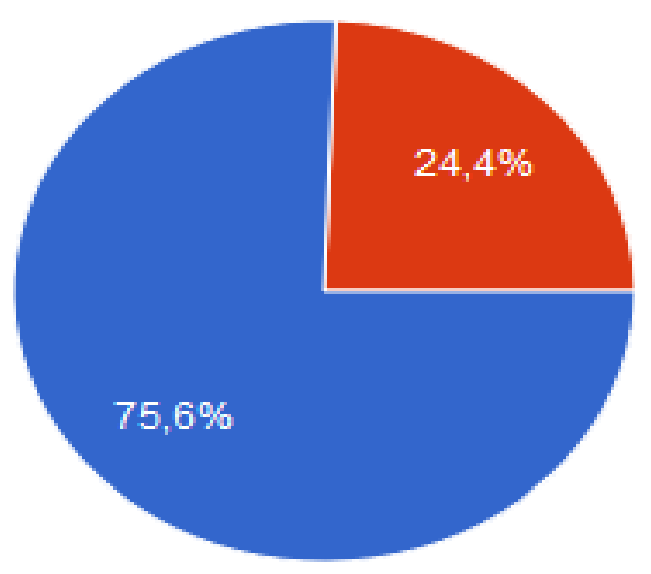

Feminino

Masculino

Figura 2. Sexo declarado pelos participantes da pesquisa.

Quanto ao estado onde reside, o de maior captação foi a Paraíba, isto se deve ao fato do nicho de conhecimento dos pesquisadores ser neste local o qual reside (Figura 3).

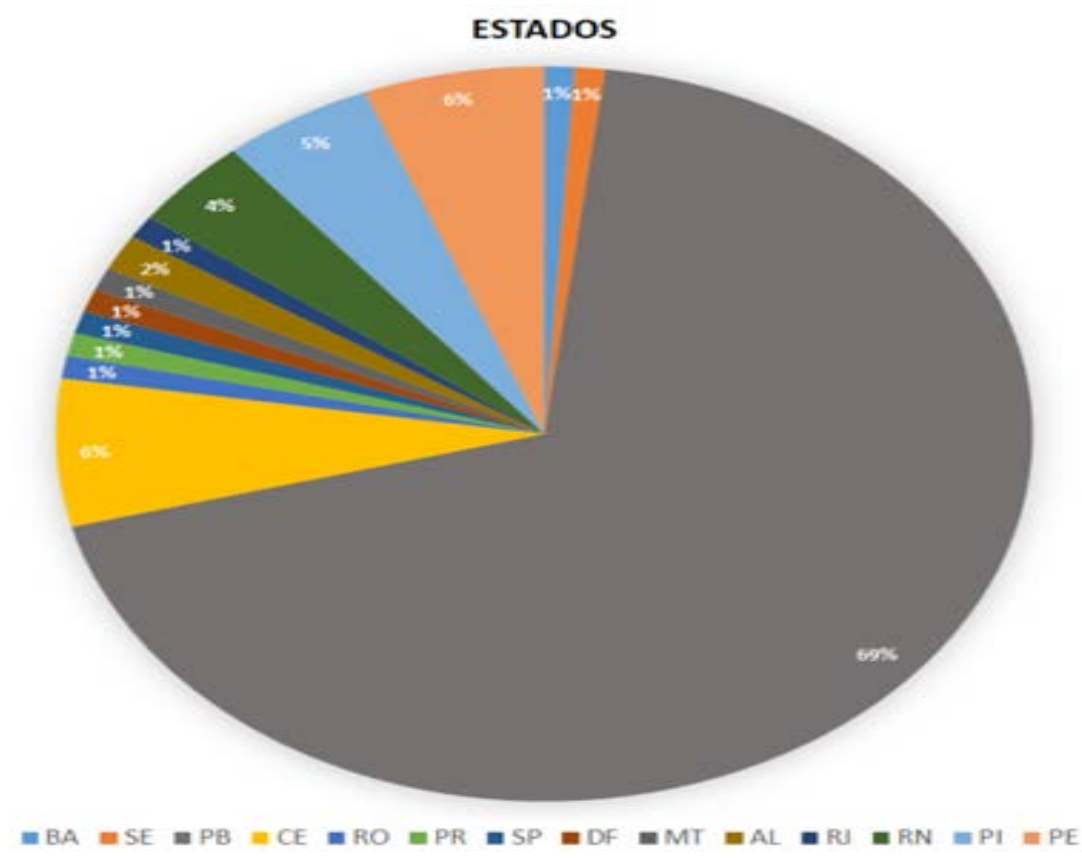

Figura 3. Estado onde residem os participantes da pesquisa. 
Quanto às profissões indicadas (Figura 4), as de maior contato com a pesquisa foram fisioterapeutas (21\%) e esteticistas (17\%), público com maior acessibilidade da pesquisadora, devido a profissão e atividade que desempenha, além destas profissionais deterem o conhecimento sobre a cosmetologia, seguido por estudantes (10\%) e professor $(8 \%)$.

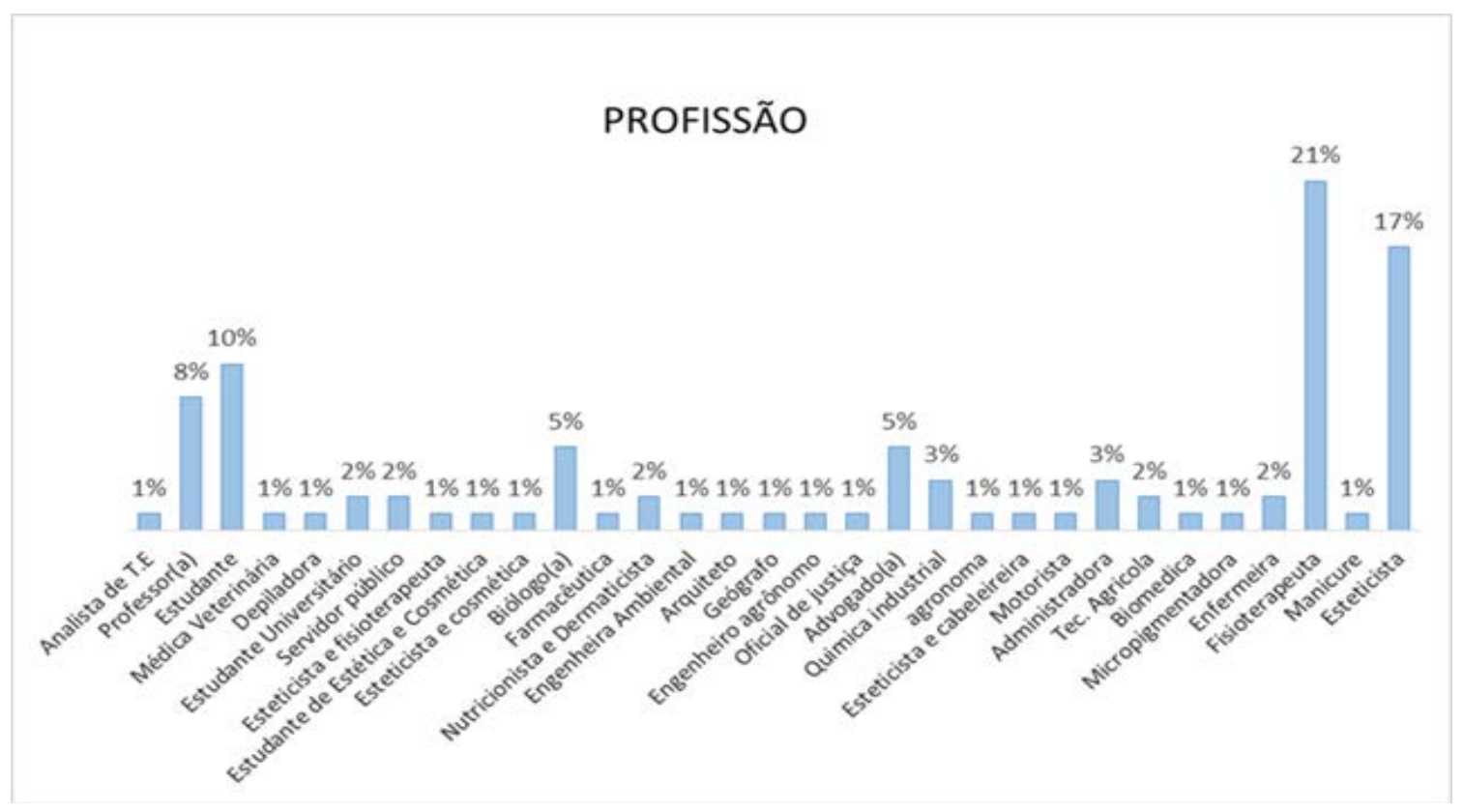

Figura 4. Profissão informada pelos participantes da pesquisa.

Foi constatado que $28,1 \%$ dos entrevistados residem no bioma da zona costeira, isto se deve que a maioria dos entrevistados reside na região da Paraíba (Figura 5). A zona costeira brasileira tem uma faixa de mais de 8 mil quilômetros, compreendendo 395 municípios distribuídos em 17 estados litorâneos: Bahia, Sergipe, Alagoas, Pernambuco, Paraíba, Piauí, Rio Grande do Norte, Ceará, Maranhão, Pará ,Amapá, Rio Grande do Sul, Santa Catarina, Paraná, São Paulo, Rio de Janeiro, Espírito Santo (MMA, 2016).

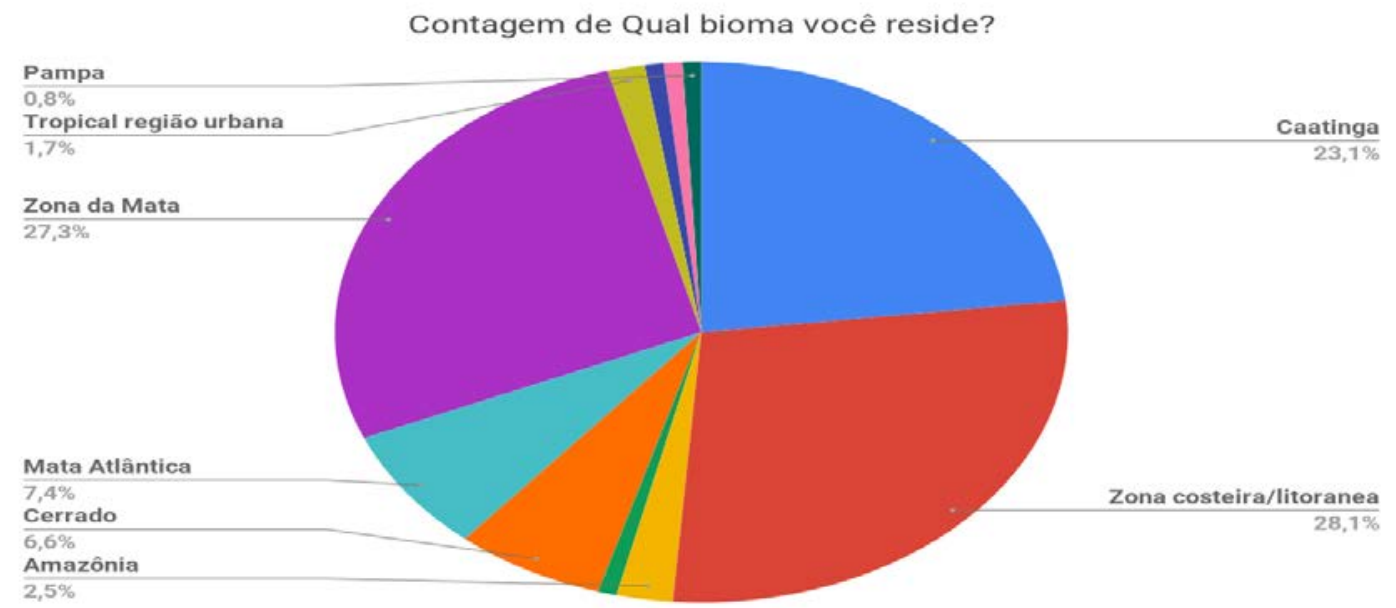

Figura 5. Bioma onde residem os participantes da pesquisa.

Rev. Bras. Gest. Amb. Sustent., 2020, vol. 7, n. 15, p. 171-191. 
A faixa de renda mensal média mais comum entre os respondentes está entre de 2 a 4 salários mínimos correspondendo a 30,1\%, seguida pela faixa até 2 s.m (23,6\%). A faixa de renda familiar média menos frequente na amostra foi a faixa de $1 \mathrm{s.m}(0.8 \%)$. Esta correlação está interligada ao maior público alcançado de Fisioterapeutas e Esteticistas, o que condiz com a realidade financeira e econômica da região (Figura 6).

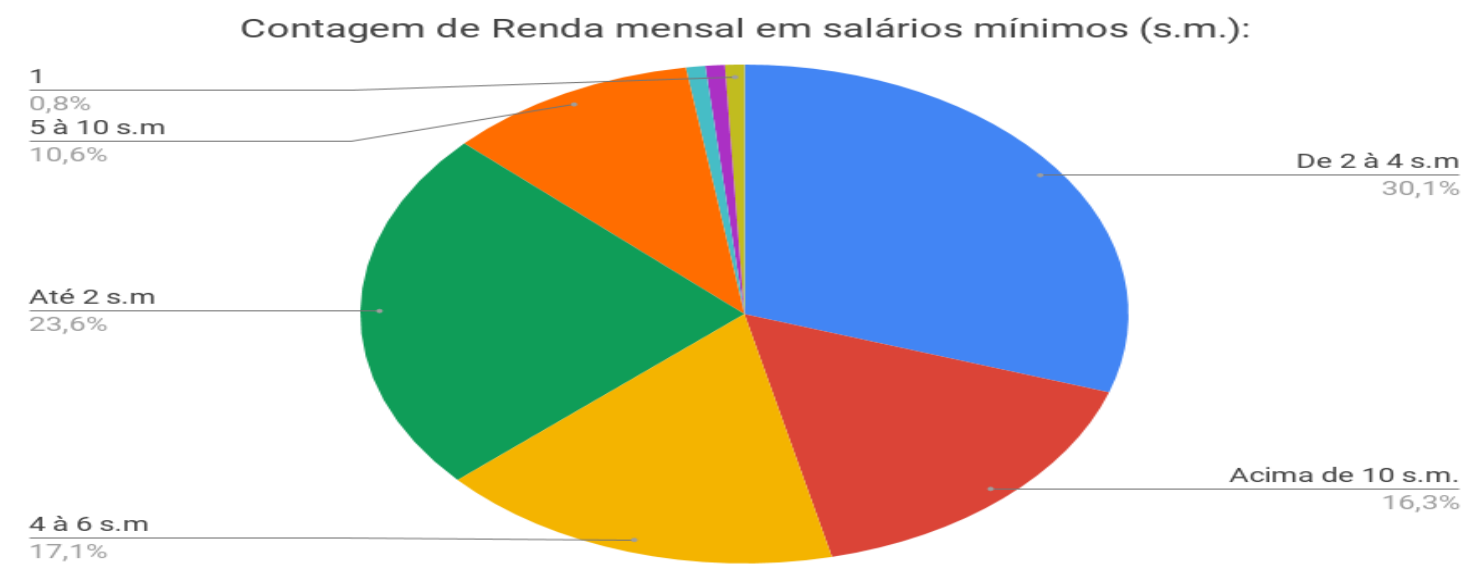

Figura 6. Renda mensal em salários mínimos (s.m.).

Quanto ao nível de escolaridade 63,4\% dos respondentes possuem nível de pósgraduação, 18,7\% o ensino superior completo, as amostras de $11,4 \%$ cursam o ensino superior incompleto e apenas $4,1 \%$ possuem como nível de escolaridade mais elevado o ensino médio (Figura 7).

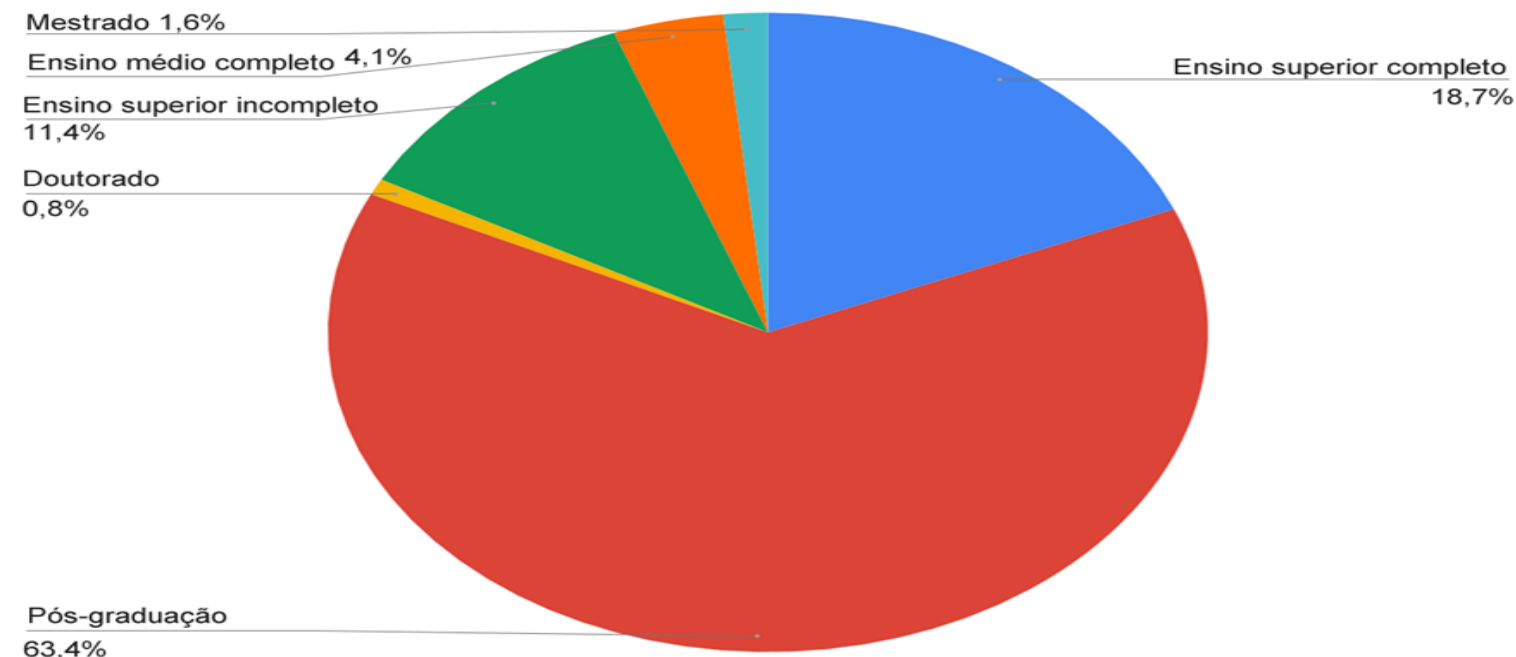

Figura 7. Escolaridade informada pelos participantes da pesquisa. 


\section{Fitocosméticos}

Dos entrevistados, 95,9\% já ouviram falar sobre produtos de cuidados pessoais de origem natural (Figura 8). Significa dizer que quase a totalidade dos entrevistados, conhecem os fitocosméticos, é interessante afirmar que o conhecimento por várias vezes é a única forma terapêutica das comunidades locais e grupos étnicos, então os consumidores de plantas medicinais, mantém a prática do consumo de fitoterápicos, acreditando nas informações terapêuticas que foram passadas durante séculos, mesmo sem terem conhecimento dos seus constituintes químicos.

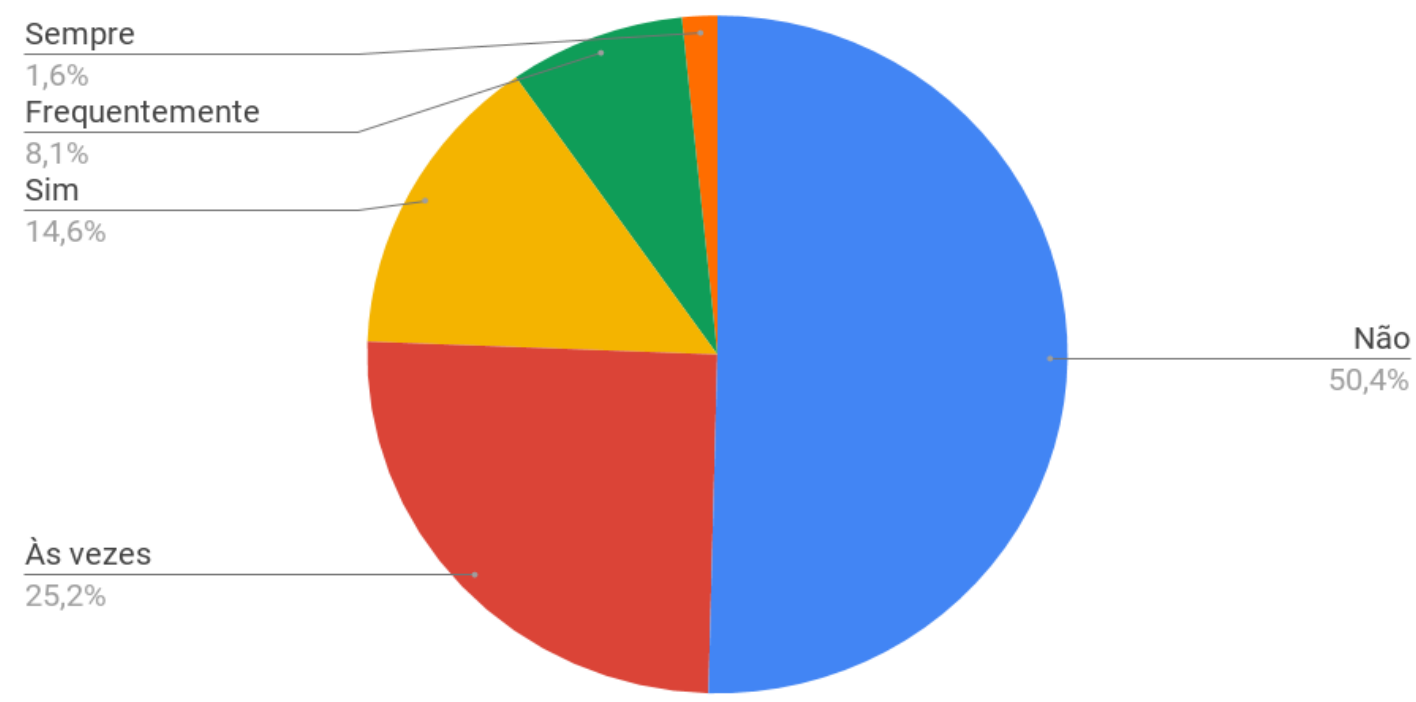

Figura 8. Respostas à pergunta se nos cuidados pessoais, costuma recorrer a alternativas caseiras.

Dos respondentes a maioria com 50,4\% responderam que não usam alternativas caseiras, seguido por $25,2 \%$ às vezes e $14,6 \%$ que utilizam. As formas mais citadas foram óleo de coco, babosa (Aloe vera) e chás para tratamento capilar.

\section{É o responsável pela escolha de produtos de cuidados pessoais que usa?} Foram obtidas 105 respostas como responsáveis pela escolha correspondendo a 85,4\%, esse quantitativo representa os benefícios que fazem para a saúde, que vai além da estética. Torna-se válido ressaltar que os cosméticos orgânicos possuem na sua constituição os derivados de fontes ricas de nutrientes como minerais, vitaminas e metabólitos secundários, que são importantes para o nosso organismo como um todo. Para que aconteça a produção dos cosméticos do tipo orgânicos, surge a partir do uso consciente dos recursos fontes naturais e da preservação do meio ambiente, oferecendo um reduzido impacto socioambiental.

Tem conhecimento sobre qual matéria prima de origem natural é utilizada nos cosméticos? Ao todo, 66 responderam que não tem conhecimento o que corresponde a 53,7\%. Este quantitativo pode ser devido à falta de uma clareza da rotulagem do produto, com termos não compreensível e muitas das vezes em língua estrangeira, o que dificulta a compreensão e o entendimento. A rotulagem é uma das principais etapas do processo da embalagem e deve conter todas as informações necessárias para que o produto seja utilizado adequadamente. 
Com base nos dados da Tabela 1, as principais matérias primas citadas pelos entrevistados foram: a babosa (Aloe vera) com 15 respostas, seguida pelos óleos essenciais com 14 respostas e o óleo e derivados do coco com 12 respostas.

Tabela 1. As matérias-primas reconhecidas pelos participantes da pesquisa.

\begin{tabular}{|c|c|c|c|c|c|c|}
\hline \multicolumn{6}{|c|}{ Parte da planta } & \multirow{2}{*}{ Algas } \\
\hline Folha & Casca & Semente & Flor & Fruto & Caule & \\
\hline Babosa & Óleos & Soja & Aveia & Coco & Bambu & Fucus vesiculosus \\
\hline Ervas & - & Linhaça & Alecrim & Abacate & $\begin{array}{l}\text { Cana de } \\
\text { açúcar }\end{array}$ & - \\
\hline Canfora & - & Amêndoas & Sálvia & Própolis & $\begin{array}{l}\text { Raiz } \\
\text { forte }\end{array}$ & - \\
\hline Mentol & - & Urucum & Camomila & Mamonas & - & - \\
\hline $\begin{array}{l}\text { Centelha } \\
\text { asiática }\end{array}$ & - & Café & Hibisco & Pitanga & - & - \\
\hline Rícino & - & Algodão & Erva doce & $\begin{array}{c}\text { Manteigas } \\
\text { vegetais }\end{array}$ & - & - \\
\hline $\begin{array}{l}\text { Cera de } \\
\text { carnaúba }\end{array}$ & - & Cacau & Aroeira & Azeite & - & - \\
\hline Arnica & - & - & Melaleuca & Bearberry & - & - \\
\hline Babacu & - & - & Mel & Jaborandi & - & - \\
\hline Hamamelis & - & - & - & Maracujá & - & - \\
\hline Cha verde & - & - & - & Algaroba & - & - \\
\hline Alcachofra & - & - & - & Gengibre & - & - \\
\hline Ginko Biloba & - & - & - & $\begin{array}{c}\text { Pimenta } \\
\text { rosa }\end{array}$ & - & - \\
\hline
\end{tabular}

Qual planta com finalidade cosmética existe na sua região? Foram coletadas 123 respostas, a maioria respondeu a babosa (Aloe vera) com 36 respostas, seguida do coco com 10 respostas.

Convém destacar de acordo com a pesquisa, as espécies de maior conhecimento dos entrevistados é a Aloe vera (babosa), seguido pelos benefícios do coco. A popularidade da Aloe vera vem das gerações que transmitiram o conhecimento aos descendentes, e com isso os seus benefícios perduraram e são comprovados cientificamente com um grande poder hidratante e anti-inflamatório que a espécie possui.

Este conhecimento deve-se por ser uma planta facilmente encontrada e muito utilizada pela indústria de cosméticos como calmante e hidratante para a pele devido às propriedades cicatrizantes e antimicrobianas, além do uso tópico ela tem um valor nutricional importante, é muito rica em manganês, magnésio, cálcio, ferro, zinco, selênio e principalmente as vitaminas do complexo $\mathrm{B}$ e sendo destaque outras vitaminas, seria a vitamina $\mathrm{C}$ e a vitamina $\mathrm{E}$. As pesquisas relatam que quando há a eliminação da parte mais externas da folha, é obtido um gel mucilaginoso, fluido e incolor, sua composição é água,polissacarídeos, além de 70 outros componentes, como as vitaminas A, B, C e E, cálcio, potássio, magnésio e zinco (Teske e Trentini, 1997; Femenia et al., 1999; Carvalho, 2005; Surjushe, 2008). Esse produto é usado como base na indústria farmacêutica, cosmética e alimentícia e diversas técnicas são utilizadas para que haja a sua conservação (Atherton, 1997; Eshun e He, 2004; Cunha, 2005).

O óleo de coco foi a segunda matéria prima citada, onde os seus benefícios para a indústria cosmética advêm do uso do ácido mirístico, que é classificado como o segundo principal ácido graxo (20\%) do óleo de coco (Kumar,2011). 
Outra matéria prima bastante citada foram os óleos essenciais, os quais são extraídos de algumas partes de plantas, possuem uma complexa composição química e comprova vantagens aos vegetais produtores (Oussalah et al., 2007). O aumento do interesse dos consumidores por produtos que tem origem de fontes naturais, está consentindo o aproveitamento dos óleos essenciais nos produtos de higiene pessoal e cosméticos,nas indústrias de alimentos e bebidas,para que não ocorra a deterioração lipídica, oxidação e a contaminação por micro-organismos destes produtos (Fraga et al., 2016).

Existe uma associação local na sua região de coleta de plantas com finalidade cosmética? As respostas foram estatisticamente classificadas com $64,2 \%$ não sabem, seguida de $25,2 \%$ não tem e $10,6 \%$ sim tem.

Esse alto índice de falta de conhecimento, pode ser explicado pelo avanço do mercado e o aparecimento de novos negócios e empresas ligadas a matéria-prima nos últimos anos, o que converge à entrada de laboratórios tecnológicos, favorecendo a pesquisa e a produção de princípios ativos modernos e com alta eficácia para a saúde da pele.

No documento final apresentado na Rio+20 relata que a população indígena e as comunidades locais são pertencentes da biodiversidade e dos ecossistemas, que se tornam acometidos diretamente da degradação do ambiente em que habitam. A sabedoria tradicional, juntamente com as práticas e inovações deste povo, é de grande valia para que haja a conservação e o uso sustentável da variedade local, favorecendo a melhoria do bemestar (Silva, 2015).

Você tem algum conhecimento que foi passado através das gerações sobre o uso das plantas com finalidades cosméticas? Neste item foram obtidas 59 respostas, e a babosa foi citada por 35 entrevistados. Confirma a popularidade da planta desde as gerações passadas e ainda com grande uso na atualidade, confirmando a riqueza de substancias para a saúde da pele e cabelos.

É interessante destacar que o "primeiro registro do uso da A. vera foi feito em uma tabuleta de argila da Mesopotâmia com data de 2100 a.C, era designada no Egito antigo como a "planta da imortalidade", sendo utilizada por Cleópatra nos cuidados do cabelo e da pele" (Alonso, 2007).

Você acha que quanto ao mercado econômico, as populações tradicionais, incluindo os indígenas, são beneficiados com a exploração de matéria -prima na suas respectivas regiões? Neste questionamento $61,8 \%$ disseram que não e $38,2 \%$ que sim. Diante da maioria das respostas serem de não benefícios, a justificativa mais aceita é que as populações "tradicionais" indígenas estejam adaptadas a um estilo de vida conectado com o ambiente, é percebido que esse povo vem sendo excluído de qualquer forma de contribuição que possa ofertar à produção de leis que regem a política pública regional. São acometidas primeiramente pela degradação do ambiente e as últimas a terem os benefícios das políticas de conservação ambiental (Sousa et al., 2016).

Aceitação dos fitocosméticos. De acordo com a pesquisa 108 pessoas acham o mercado de fitocosméticos promissor e 87 responderam que são bem aceitos pelos consumidores. Podemos exemplificar, que os extratos e óleos da forma como é divulgada os seus benefícios, o comércio, e o uso na indústria são mentores de novas potencialidades no contexto social, político e econômico, além da capacidade existente em biotecnologias para serem executadas em específicas áreas geoeconômicas e geopolíticas da maior região que é a Amazônia (Costa e Nunez, 2016). 


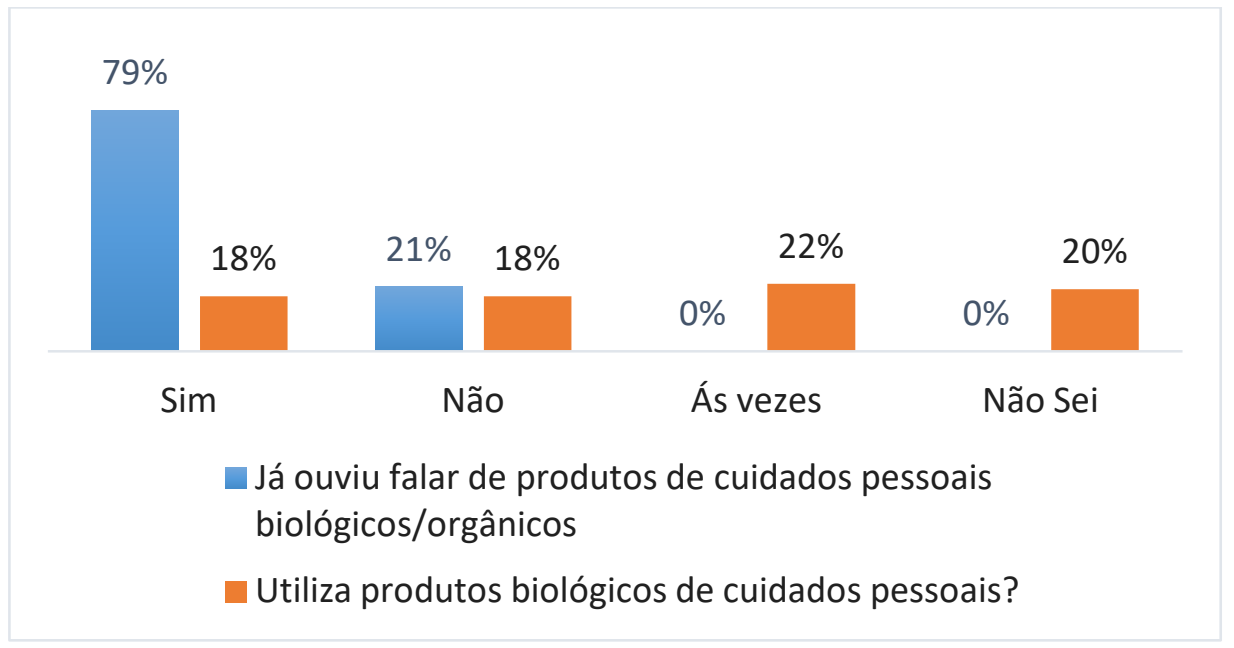

Figura 9. Você acha que o mercado dos fitocosméticos é promissor? Na sua visão os fitocosméticos são bem aceitos pelos consumidores?

\section{Preocupações ambientais}

É interessante destacar que a maioria dos entrevistados consideram importante a proteção ao ambiente $(n=118)$, que adquirem produtos ambientalmente seguros $(\mathrm{n}=119)$, compreendem os rótulos $(\mathrm{n}=90)$ e priorizam a aquisição de produtos que respeitem a natureza $(n=95)$.

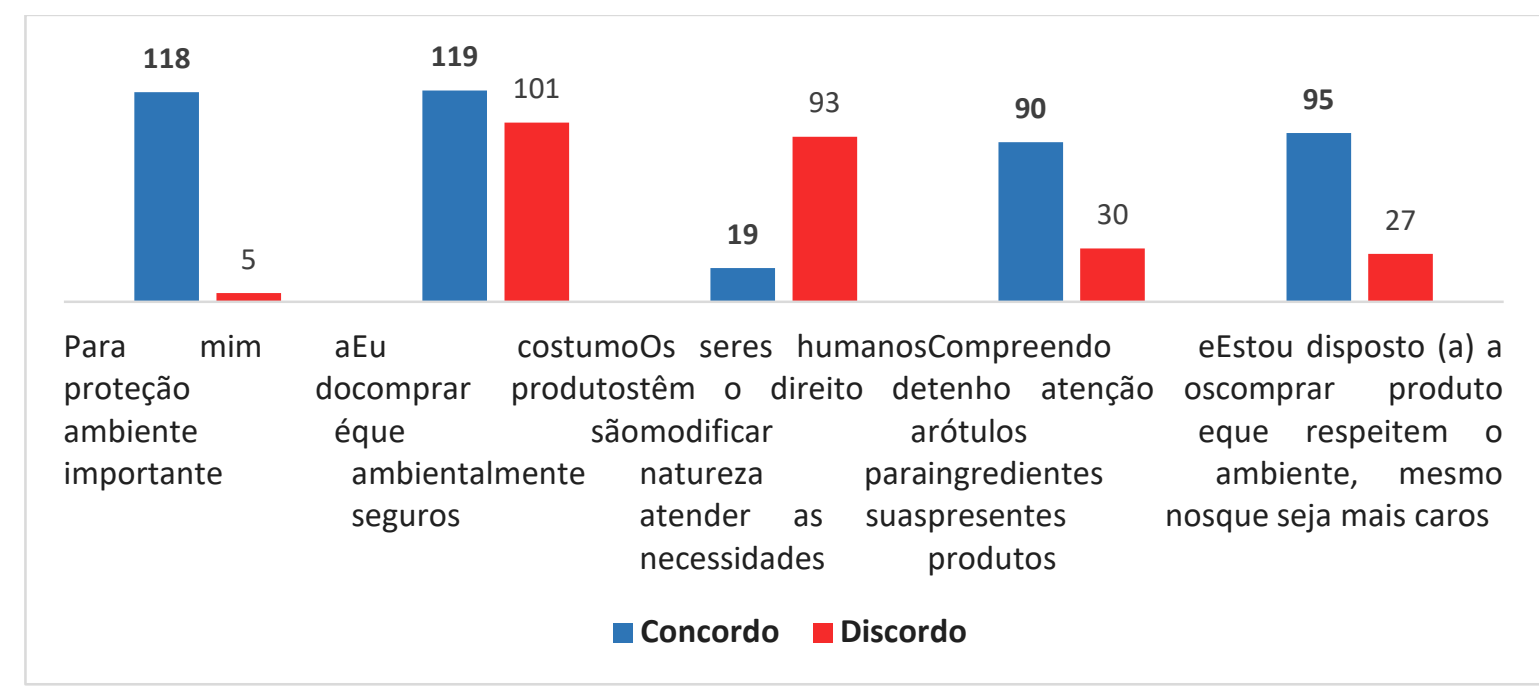

Figura 10. Por favor, leia as seguintes informações e assinale o seu grau de concordância.

Esta consciência da população, originou-se através do marketing verde que foi disseminado através do conceito de sustentabilidade, a qual após a divulgação do relatório Brundtland (1987), quando os problemas sociais e ecológicos passaram a ter uma certa influência em empresas e na economia, além de demandar mudanças fundamentais a longo prazo no paradigma de gestão empresarial. Assim, o marketing verde pode ser conceituado como "o processo holístico de gestão que identifica, antecipa e satisfaz as 
necessidades dos consumidores de modo rentável e sustentável" (Peattie e Charter, 2003, p. 727). A partir deste eixo de sustentabilidade foi capaz de permitir a ligação entre a preocupação ambiental e o marketing, com objetivo de estimular e facilitar o consumo de bens e serviços (Peattie, 2008).

Você se preocupa em adquirir produtos de empresas que possua consciência ecológica e utiliza o selo verde? Neste item, houve a totalidade de respostas pelos entrevistados, onde 79,7\% afirmaram que se preocupam e 20,3\% que não tem preocupação.

É importante a consciência do consumidor quanto a preocupação da certificação dos produtos, pois as empresas podem usar o termo de produtos naturais ou fitocosméticos sem serem certificadas, o que pode causar danos à saúde da pele. A função das certificadoras é justamente fiscalizar e testar os produtos, confirmando os benefícios que ela oferece ao consumidor. Ser um cosmético chamado verde é ter a veracidade, idoneidade e confiança do consumidor.

Você tem consciência de que a empresa fabricante dos cosméticos que você adquiriu tem ações ambientais? A porcentagem de respostas foi de $40,7 \%$ que não tem consciência e 54,3\% que tem consciência das ações ambientais das empresas que adquirem os seus produtos.

Para justificar a importância de adotar práticas ambientais pelas e empresas, primeiramente deve acontecer através da redução do volume de resíduos gerados, trazendo benefícios ao meio ambiente e com isso há redução dos custos de produzir. É fato que existe um elevado custo para que os resíduos sejam tratados e operacionalizados durante a produção dos cosméticos. Seguindo esta linha de raciocínio, é interessante que as embalagens dos cosméticos sejam levadas em consideração e avaliadas, pois elas têm ciclo de vida peculiar, sendo um componente do lixo urbano, portanto deve ser avaliada toda a cadeia produtiva, o que abrange desde a produção até o descarte. No Guia Técnico Ambiental da CETESB (2012), é citada a ligação estabelecida pelas empresas produtoras de cosméticos com seus fornecedores de matérias-primas, de produtos semiacabados e de embalagens, é necessário garantir a sustentabilidade ao negócio, da mesma forma como em outros setores industriais (Gonçalves e Henkes, 2016).

\section{Consumo de produtos de cuidados pessoais}

Foi perguntado aos respondentes, quanto a ordem de importância de uso dos cosméticos com diferentes finalidades, $50 \%$ responderam que não usam cosméticos, seguido por $38 \%$ que usam maquiagem, $30 \%$ usam protetor solar, $29 \%$ usam produtos para o corpo, $27 \%$ utilizam produtos para o rosto, $27 \%$ usam perfumes, $26 \%$ utilizam produtos para o cuidado dos cabelos, $26 \%$ produtos para higiene intima, $26 \%$ usam produtos para higiene oral.

A ABIHPEC anuncia que nos últimos 20 anos, o setor teve crescimento que gira em torno de 11,5\% (ao ano). 0 Brasil já ocupou o $3^{\circ}$ lugar dos líderes mundiais e desde o ano de 2017, o Brasil ocupa a quarta posição no ranking mundial do setor, com uma fatia de 6,9\% do mercado mundial, atrás dos Estados Unidos, China e Japão. Os produtos com maior índice de vendas em 2016 são os cremes hidratantes, as espumas e itens de cuidados para a barba, quanto aos produtos de cuidados pessoais, surge pela primeira vez entre os cosméticos mais utilizados, os produtos para cabelos, os voltados para a higiene pessoal estão o sabonete, creme dental e protetor solar são os mais vendidos (ABIHPEC, 2018). 

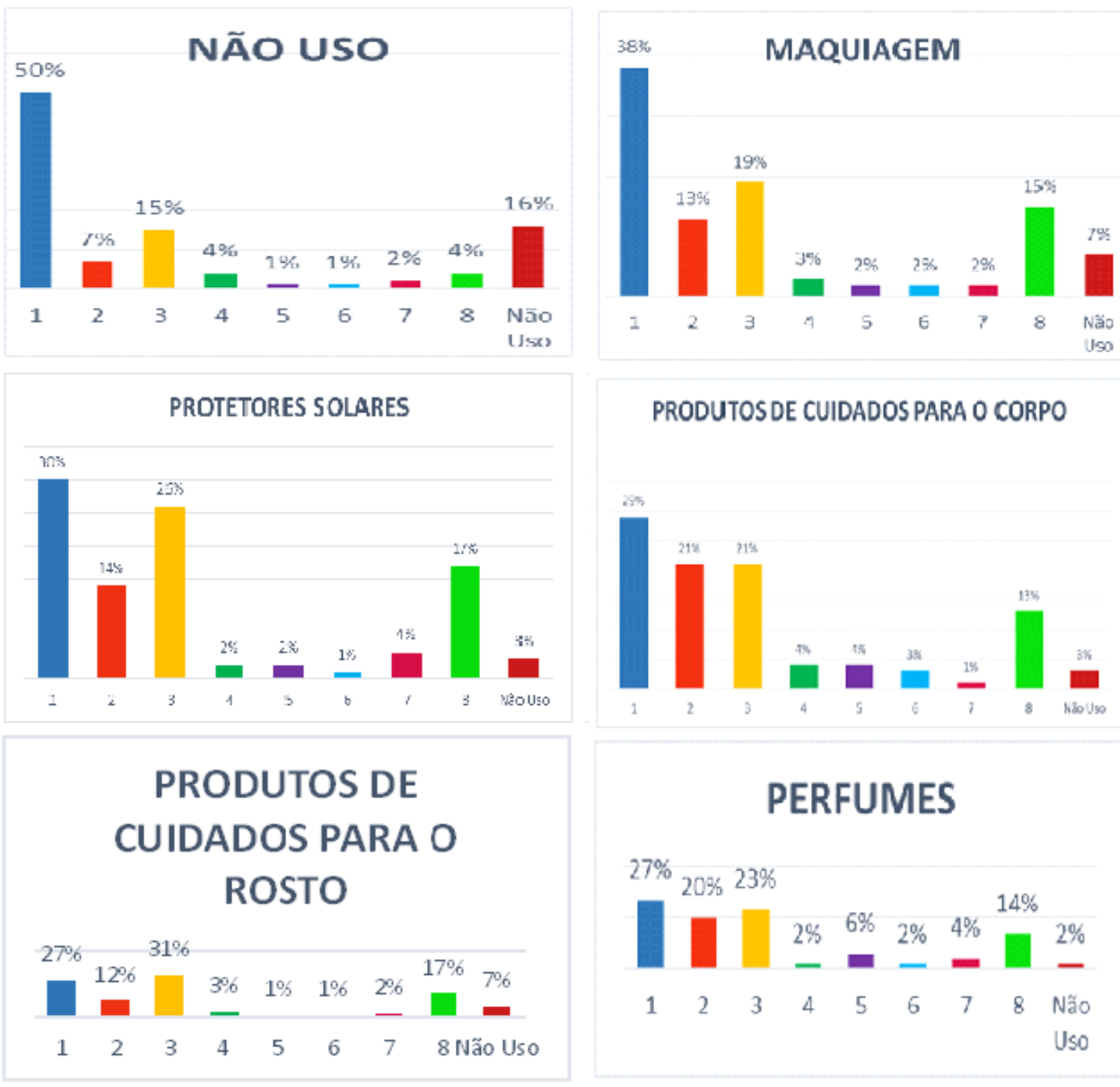

PRODUTOSDE CUIDADOS PARA O CORPO

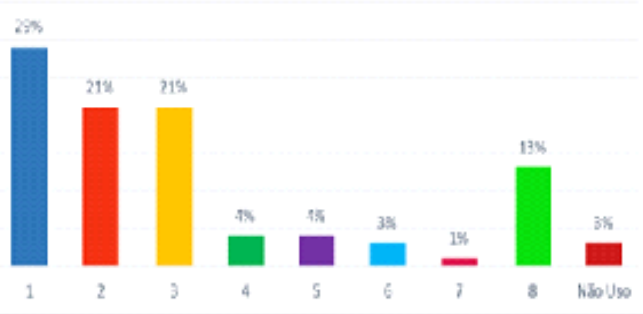

\section{PERFUMES}
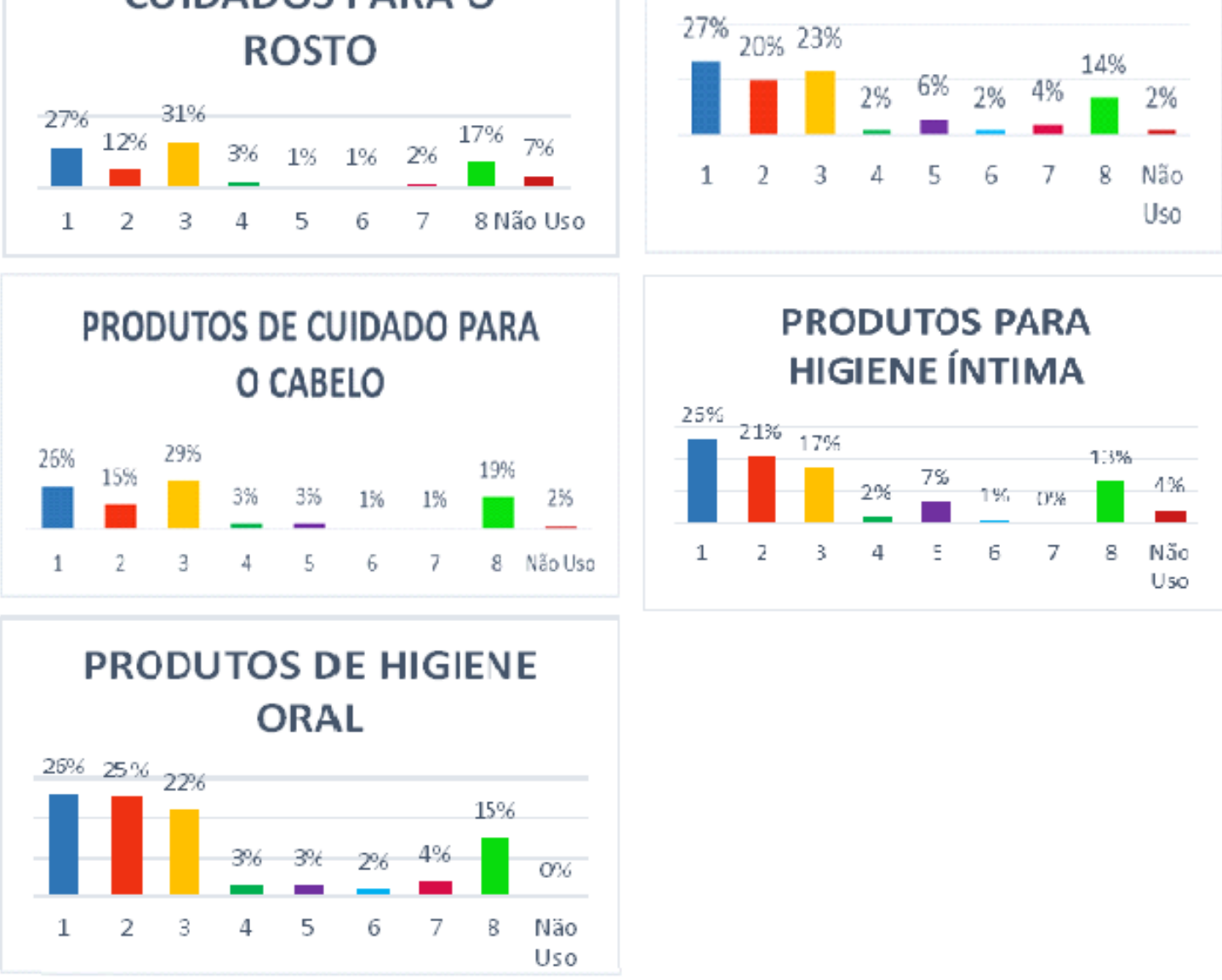

Figura 11. Associação da designação produtos de cuidados pessoais "naturais". 
A maioria dos respondentes $(n=26 \%)$ afirmaram que produtos de cuidados pessoais naturais, são aqueles que têm ingredientes naturais (Figuras 11 e 12). 0 termo "cosmético verde" está voltado a ser um produto "ambientalmente amigável" e com a utilização de componentes naturais, orgânicos (Leja e Ross-Fichtner, 2014) ou veganos. Deve-se entender que o desenvolvimento, a pesquisa e a produção dos cosméticos naturais e orgânicos possui como forma de preparo, a exclusão dos métodos de produção tradicionais, o estímulo à procura de ingredientes alternativos naturais e à produção sustentável, de forma que gere um menor impacto ao meio ambiente durante o ciclo de vida do produto (Fonseca-Santos et al., 2015).

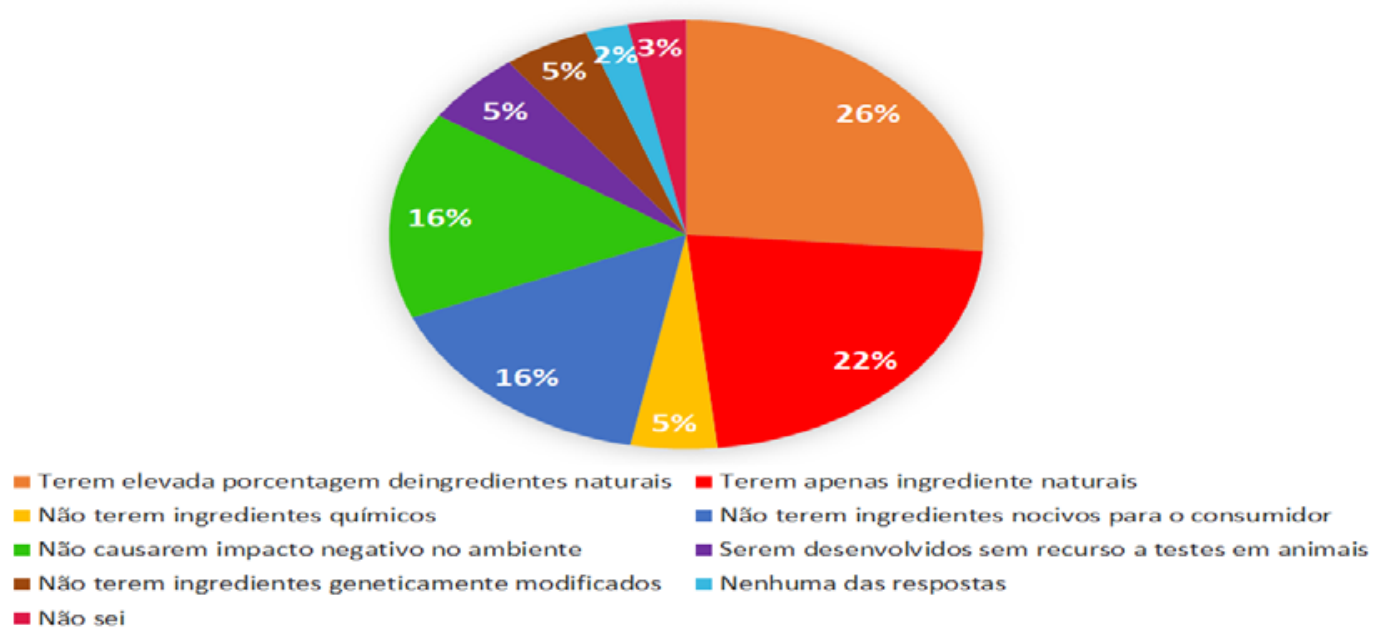

Figura 12. Já ouviu falar de produtos de cuidados pessoais biológicos/orgânicos? Utiliza produtos biológicos de cuidados pessoais?

Os respondentes do questionário também foram solicitados a expressar seu grau de conhecimento e utilização dos produtos biológicos de cuidados pessoais (Figura 13). Mostraram, em sua maioria (79\%), o entendimento de que já ouviram falar dos produtos e $22 \%$ utilizam às vezes os produtos. É interessante destacar que nas últimas décadas, a propagação do conceito e de práticas voltadas à sustentabilidade em âmbito mundial, as preocupações éticas relacionadas à produção e consumo de cosméticos (Sahota, 2014), bem como a constatação de efeitos prejudiciais causados por aditivos químicos presentes em cosméticos à saúde humana (Juhász e Marmur, 2014), ao meio ambiente e aos organismos nele presentes (Brausch e Rand, 2011) instigaram o surgimento e a ampliação da demanda pelos chamados "cosméticos verdes".

Da amostra coletada 20\% responderam que associam produtos biológicos/ orgânicos os que possuem apenas ingredientes naturais, seguido dos que tem ingredientes provenientes da agricultura biológica com 15\% e 13\% afirmaram que são produtos que não causam impacto negativo ao ambiente (Figura 14). 


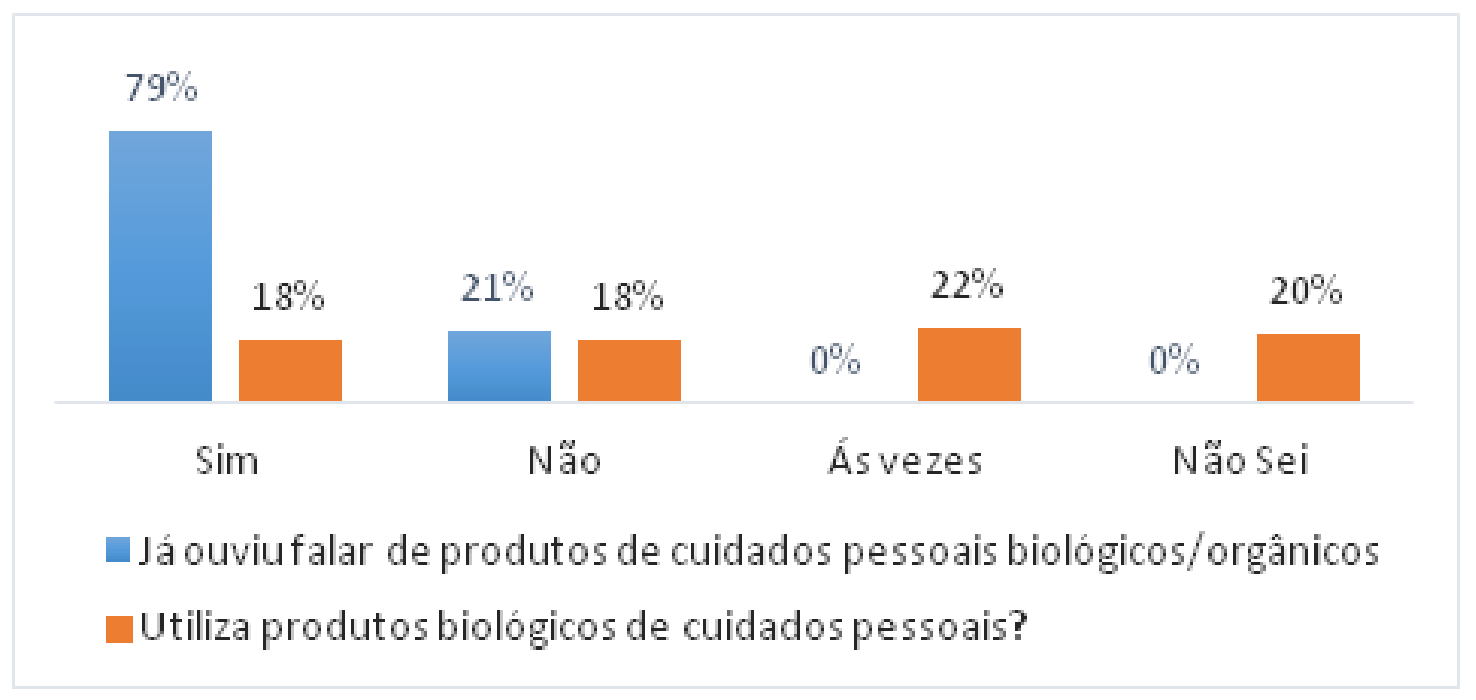

Figura 13. Associação de produto com a designação "produto de cuidados pessoais biológico/orgânico".

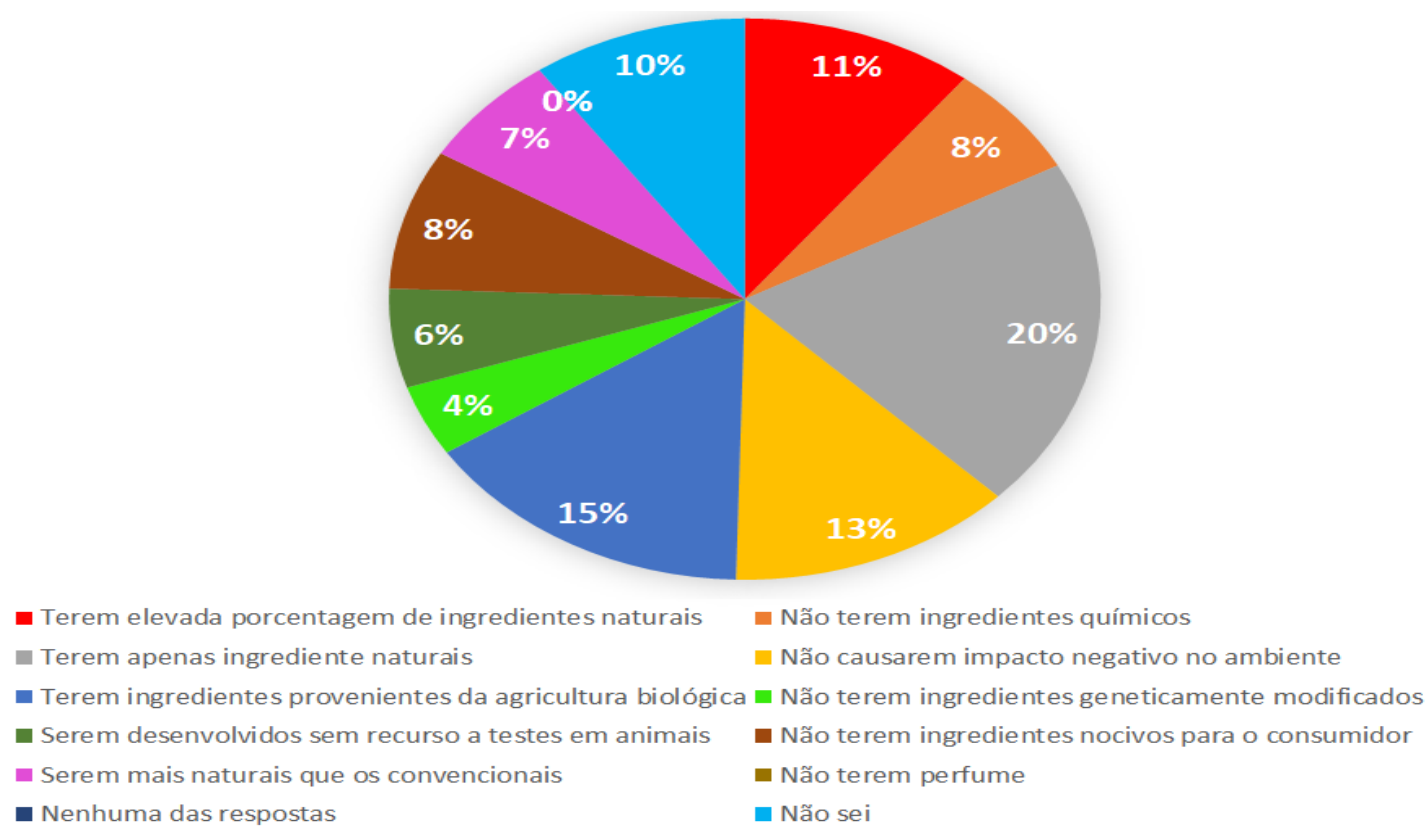

Figura 14. Associação de produtos biológicos/orgânicos.

Os respondentes majoritariamente afirmaram com $41 \%$, que se preocupam com os ingredientes que são nocivos à saúde, seguido por $27 \%$ pela questão de saúde e em terceiro lugar com 19\% a preocupação com o ambiente. A preocupação quando se fala em segurança dos produtos cosméticos, é devido ao fato de serem classificados de venda livre, ou seja, o consumidor pode comprá-lo quando quiser, não sendo necessário a intervenção de um profissional da saúde. Os problemas relativos ao uso de produtos cosméticos, envolve desde ocorrências relacionados a defeitos na embalagem, instabilidade de ativos cosméticos até o surgimento de reações alérgicas, irritações e infecções, tais motivos sempre existiram, porém por muitas vezes não houve acionamento de registros e 
encaminhamento a ANVISA. Sendo assim, na maioria das vezes, o como não tinha essa queixa por parte do consumidor, o resultado consistia na desistência do uso do produto (Behrens, 2007).

Partindo destas afirmações, surge o termo cosmetovigilância, que se encontra sob à "edição da Portaria no 348 de agosto de 1997, que obriga a todos os estabelecimentos produtores de Produtos de Higiene Pessoal, Cosméticos e Perfumes, o cumprimento das Diretrizes estabelecidas no Regulamento Técnico - Manual de Boas Práticas de Fabricação para Produtos de Higiene Pessoal, Cosméticos e Perfumes (ANVISA)". A mesma pode ser compreendida como uma forma que assegura o consumidor conferir se o fabricante está cumprindo as recomendações, com isso há redução das ocorrências de não conformidades e sua ação toxica poderá ser potencialmente reduzida ou até inexistir (Trevisan, 2006).

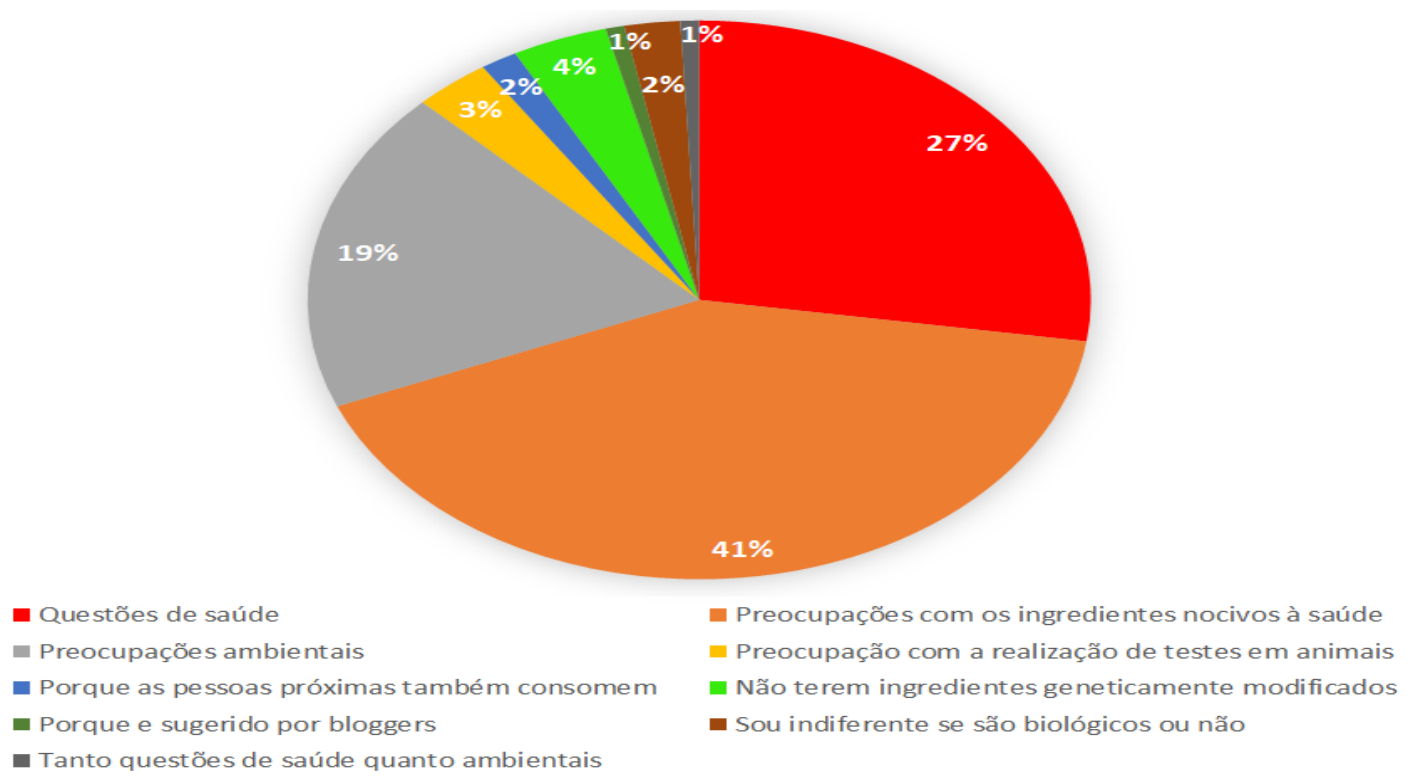

Figura 15. Principais razões que levariam os participantes da pesquisa a escolher estes produtos em detrimento dos convencionais?

\section{Considerações finais}

Na ampliação do mercado de cosméticos verde, a pesquisa se propôs a analisar a percepção consumidores de cosméticos em relação ao seu conhecimento relacionado aos extratos vegetais presente nos cosméticos. Para tanto, foi adotado como referencial teórico o levantamento das principais matérias primas das regiões da Amazônia e Caatinga, bem como seu potencial econômico e exploratório, levando em consideração sua biodiversidade

Com base nos resultados obtidos na pesquisa, verificou-se que os consumidores, mesmo como todo avanço das empresas em produzirem cosméticos com as mais variadas matérias primas, a resposta dos entrevistados girou em torno de extratos de uso popular e tradicionais, como a aloe vera e os derivados do coco.

A Aloe vera "é uma planta herbácea que cresce em qualquer tipo de solo, mas é melhor adaptada aos leves e arenosos e não exige muita água, demora de quatro a cinco anos para atingir a maturidade. 0 gel presente na parte interna das folhas é muito 
utilizado como matéria prima na indústria cosmética, alimentícia e farmacêutica e diversas técnicas são empregadas para sua conservação".

Foi concluído que a maioria dos consumidores não recorrem mais as alternativas caseiras, isso deve-se ao avanço do mercado industrial e a acessibilidade das pessoas ao produto finalizado, o que facilita a aquisição e a credibilidade em ser de origem natural ou biológica.

A percepção dos consumidores mudou com a questão da conscientização para a preservação ambiental e sustentabilidade, acreditando que usando o natural, está poupando a natureza, o que de fato se justifica. Oferecendo aos seus cuidados estéticos produtos com origem natural e com baixo risco de toxicidade a saúde da pele.

Outro ponto que merece ser destacado é o mercado econômico de ambas regiões. Na região amazônica os principais extratos que fazem o maior fluxo financeiro é o açaí, cupuaçu, a andiroba e o buriti, que são coletados pelos extrativistas e vendidos as empresas as quais fornecem por baixo custo, e compram com alto custo o produto finalizado, o que gera um déficit econômico de acordo com os autores da bioeconomia local.

Esta rotatividade econômica, não é tão destacada na caatinga, mesmo sendo um bioma rico e com grandes potencialidades, porém pelos estudos pode ser observado, que falta um olhar para as riquezas locais, pelas empresas do ramo, falta o interesse dos pesquisadores em investir nas inovações, pesquisas e tecnologia para ampliar a visão da região e fazer as descobertas pertinentes à área da cosmetologia.

As plantas com potencial para produção de cosméticos na região da caatinga, mas especificadamente na faixa do Nordeste, é o umbu, alecrim do campo, jatobá, velame e aroeira, a mesma tem potencial para servir como fonte de renda para as comunidades locais, se os diretores e pesquisadores das empresas produtoras voltarem à atenção para a atribuição aromática e terapêutica destas espécies.

Mesmo sendo áreas com grandiosidades e riquezas bem diferentes, com nível de exploração discrepante, o que se pode observar em comum as duas áreas, é que precisam ainda serem mais exploradas em suas potencialidades locais. A região da Amazônia, conta apenas com cerca de $10 \%$ da sua área explorada para a finalidade cosmética, o que deixa 0 Brasil como o principal fornecedor de matéria prima, diante de uma pequena parte de todo o universo que consiste a região, e a Caatinga mesmo com algumas poucas pesquisas descrevendo seus extratos com finalidade cosmética, seu território encontra-se em mais de $50 \%$ devastado, o que pode contribuir para a extinção dos extratos sem que seja utilizado.

Assim, o trabalho se propôs a oferecer contribuições práticas e teóricas para a expansão do conhecimento e do mercado de cosméticos naturais e orgânicos, não esgotando, contudo, as possibilidades de novos estudos sobre cosméticos verdes. Sendo assim, são recomendadas novas pesquisas que abordem esse tema utilizando diferentes métodos e abordagens, para tal finalidade.

\section{Conflito de interesses}

Os autores declaram não haver conflito de interesses.

\section{Referências}

ABIHPEC - Associação Brasileira da Indústria de Higiene Pessoal, Perfumaria e Cosméticos. 2018. Disponível em: <www.abihpec.org.br>. Acesso em: 16 mar. 2019.

Alonso, J. Tratados de fitofarmacos y nutraceuticos. 2. ed. Argentina: Corpus Editorial, 2007. 
Araújo, A. I. F.; Lima, E. P.; Silva, G. A.; Santos, O. H.; Soares, T. F. Plantas nativas do Brasil empregadas em fitocosmética. Anais da X Jornada de Ensino, Pesquisa e Extensão, Recife, 2010.

Atherton, P. Aloe vera revisited. The British Journal of Phytotherapy, v. 4, n. 4, p. 176183, 1997.

Baltar, F.; Brunet, I. Social research 2.0: Virtual snowball sampling method using Facebook. Internet Research, v. 22, n. 1, p. 57-74, 2012. https://doi.org/10.1108/106622412 11199960

Behrens, I.; Chociai, J. G. A cosmetovigilância como instrumento para a garantia da qualidade na indústria de produtos cosméticos. Visão Acadêmica, v. 8, n. 1, p. 31-35, 2007. https://doi.org/10.5380/acd.v8i1.11663

Brasil. Resolução ANVISA DC no 07, de 10 de fevereiro de 2015. Dispõe sobre os requisitos técnicos para a regularização de produtos de higiene pessoal, cosméticos e perfumes e dá outras providências. Disponível em: <http://portal.anvisa.gov.br/ documents/10181/2867685/RDC_07_2015_.pdf>. Acesso em: 09 ago. 2019.

Brausch, J.; Rand, G. A review of personal care products in the aquatic environment: Environmental concentrations and toxicity. Chemosphere, v. 82, n. 11, p. 1518-1532, 2011. https://doi.org/10.1016/j.chemosphere.2010.11.018

Brundtland, G. H. Nosso futuro comum. Rio de Janeiro: FGV, 1987.

Camargos, C.; Mendonça, C.; Duarte, S. Da Imagem visual do rosto humano: simetria, textura e padrão. Saúde e Sociedade, v. 18, p. 395-410, 2009.

Carvalho, J. C. T. Formulário médico-farmacêutico de fitoterapia. 2. ed. São Paulo: Pharmabooks, 2005.

CETESB - Companhia Ambiental do Estado de São Paulo. Qualidade das praias litorâneas no Estado de São Paulo. São Paulo: CETESB, 2012.

Costa, R. C; Nunez, C. V. Mercado de bioprodutos fitoterápicos e fitocosméticos: gestão, tecnologias e inovação. Revista Fitos, v. 10, n. 3, p. 220-372, 2016. https://doi.org/10.5935/2446-4775.20160023

Cunha, A. P. Farmacognosia e Fitoquímica. 1. ed. Lisboa: Fundação Calouste Gulbenkian, 2005.

Eshun, K.; He, Q. Aloe vera: A valuable ingredient for the food, pharmaceutical and cosmetic industries - a review. Critical Reviews in Food Science and Nutrition, v. 44, n. 2, p. 91-96, 2004.

Femenia, A.; Sánchez, E. S.; Simal, S.; Rosseló, C. Compositional features of polysaccharides from Aloe vera (Aloe barbadensis Miller) plant tissues. Carbohydrate Polymers, v. 39, n. 2, p. 109-117, 1999. https://doi.org/10.1016/S0144-8617(98)00163-5

Figueiredo, B. Desenvolvimento e estabilidade preliminar de um fitocosmético contendo extrato de chá verde (Camellia sinensis) (L.) Kuntze (Theaceae). Revista Brasileira de Farmácia, v. 95, n. 2, p. 770-788, 2014.

Fonseca-Santos, B.; Corrêa, M. A.; Chorilli, M. Sustainability, natural and organic cosmetics: Consumer, products, efficacy, toxicological and regulatory considerations. Brazilian Journal of Pharmaceutical Sciences, v. 51, n. 1, p. 17-26, 2015. https://doi.org/10.1590/S1984-82502015000100002 
Forzza, R. C.; Baumgratz, J. F. A.; Bicudo, C. E. M.; Carvalho Jr., A. A.; Costa, A.; Costa, D. P.; Hopkins, M.; Leitman, P. M.; Lohmann, L. G.; Maia, L. C.; Martinelli, G.; Menezes, M.; Morim, M. P.; Coelho, M. A. N.; Peixoto, A. L.; Pirani, J. R.; Prado, J.; Queiroz, L. P.; Souza, V. C.; Stehmann, J. R.; Sylvestre, L. S.; Walter; B. M. T.; Zappi, D. Introdução: síntese da diversidade brasileira. In: Forzza, R. C.; Baumgratz, J. F. A.; Bicudo, C. E. M.; Carvalho Jr., A. A.; Costa, A.; Costa, D. P.; Hopkins, M.; Leitman, P. M.; Lohmann, L. G.; Maia, L. C.; Martinelli, G.; Menezes, M.; Morim, M. P.; Coelho, M. A. N.; Peixoto, A. L.; Pirani, J. R.; Prado, J.; Queiroz, L. P.; Souza, V. C.; Stehmann, J. R.; Sylvestre, L. S.; Walter; B. M. T.; Zappi, D. Catálogo de plantas e fungos do Brasil. Rio de Janeiro: Andrea Jakobsson Estúdio, Instituto de Pesquisa Jardim Botânico do Rio de Janeiro, 2010. v. 1. p. 19-42.

Fraga, H.; Atauri, I. G. C.; Malheiro, A. C.; Santos, J. A. Modelling climate change impacts on viticultural yield, phenology and stress conditions in Europe. Global Change Biology, v. 22, n. 11, p. 3529-3828, 2016. https://doi.org/10.1111/gcb.13382

Galembeck, F.; Csordas, Y. Cosméticos: a química da beleza. Sala de Leitura, 2009. Disponível em: <http://fisiosale.com.br/assets/9noções-de-cosmetologia-2210.pdf>. Acesso em: 06 ago. 2019.

Gonçalves, J.; Henkes, J. Produção de cosméticos de forma mais sustentável. Revista de

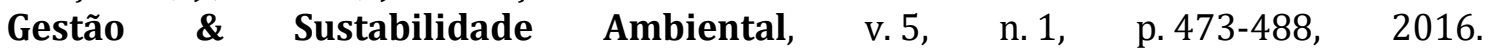
https://doi.org/10.19177/rgsa.v5e12016473-488

Isaac, V. L. B.; Cefali, L. C.; Chiari, B. G.; Oliveira, C. C. L. G.; Salgado, H. R. N.; Corrêa, M. A. Protocolo para ensaios físico-químicos de estabilidade de fitocosméticos. Revista de Ciências Farmacêuticas Básica e Aplicada, v. 29, n. 1, p. 81-96, 2008.

Kumar, N. Variabily in coconut (Coco nucifera L.) germplasm and hybrids for fatty acid profile of oil. Journal of Agricultural Food Chemistry, v. 59, p. 1350-1358, 2011.

Leja, P.; Ross-Fichtner, R. What green means for cosmetics. Cosmetics \& Toiletries, 2014. Disponível em: <http://www.cosmeticsandtoiletries.com/regulatory/organic/WhatGreen-Means-For-Cosmetics-premium-265533121.html>. Acesso em: 06 ago. 2019.

Lyrio, E.; Ferreira, G.; Zuqui, S.; Silva, A. Plant resources in biocosmetic: A new conception beauty, health, and sustainability. Natureza Online, v. 9, n. 1, p. 47-51, 2011.

Juhász, M.; Marmur, E. S. A review of selected chemical additives in cosmetic products. Dermatology Therapy, v. 27, n. 6, p. 317-322, 2014.

Maia, J. M.; Sousa, V. F. O.; Lira, E. H. A.; Lucena, A. M. A. Motivações socioeconômicas para a conservação e exploração sustentável do Bioma Caatinga. Desenvolvolvimento e Meio Ambiente, v. 41, p. 295-310, 2017. https://doi.org/10.5380/dma.v41i0.49254

Marconi, M.; Lakatos, E. Técnicas de pesquisa: planejamento e execução de pesquisas, amostragens e técnicas de pesquisas, elaboração, análise e interpretação de dados. 5. ed. São Paulo: Atlas, 2002.

MMA - Ministério do Meio Ambiente. Estudo reúne dados sobre a zona costeira. 2016. Disponível em: <http://revistaecoturismo.com.br/turismo-sustentabilidade/estudoreune-dados-sobre-a-zona-costeira>. Acesso em: 06 ago. 2019.

Oussalah, M.; Caillet, S.; Saucier, L.; Lacroix, M. Inhibitory effects of selected plant essential oils on the growth of four pathogenic bacteria: E. coli 0157:H7, Salmonella typhimurium, Staphylococcus aureus and Listeria monocytogenes. Food Control, v. 18, n. 5, p. 414-420, 2007. https://doi.org/10.1016/j.foodcont.2005.11.009

Peattie, K. Green marketing. In: Baker, M.; Hart, S. The marketing book. 6 ed. Oxford: Elsevier, 2008. p. 562-582. https://doi.org/10.1016/B978-0-7506-8566-5.50032-7 
Peattie, K.; Charter, M. Green marketing. In: Baker, M. J. The marketing book. Massachusetts: Butterworth-Heinemann, 2003. p. 726-756.

Sahota, A. Sustainability: How the cosmetics industry is greening up. London: John Wiley \& Sons, 2014.

Silva, A. T. R. A conservação da biodiversidade entre os saberes da tradição e a ciência. Estudos Avançados, v. 29, n. 83, p. 233-259, 2015. https://doi.org/10.1590/S010340142015000100012

Sousa, K.; Santoyo, A. H.; Rocha Junior, W. F.; Matos, M. R.; Silva, A. C. Bioeconomia na Amazônia: uma análise dos segmentos de fitoterápicos \& fitocosméticos, sob a perspectiva da inovação. Fronteiras: Journal of Social, Technological and Environmental Science, v. 5, n. 3, p. 151-171, 2016. https://doi.org/10.21664/2238-8869.2016v5i3.p151-171

Surjushe, A.; Vasani, R.; Saple, D. G. Aloe vera: A short review. Indian Journal of Dermatology, v. 53, n.4, p.163-166, 2008. https://doi.org/10.4103/0019-5154.44785

Teske, M.; Trentini, A. Herbarium: compêndio de fitoterapia. Curitiba: Herbarium Laboratório Botânico, 2001.

Trevisan, C. A. Cosmetovigilância e BPF. Cosmetics e Toiletries, v. 18, p. 44, 2006.

Informação da Licença: Este é um artigo Open Access distribuído sob os termos da Licença Creative Commons Attribution, que permite uso irrestrito, distribuição e reprodução em qualquer meio, desde que a obra original seja devidamente citada. 